\title{
Video Article \\ Bacterial Artificial Chromosomes: A Functional Genomics Tool for the Study of Positive-strand RNA Viruses
}

\author{
Sang-Im Yun ${ }^{1}$, Byung-Hak Song ${ }^{1}$, Jin-Kyoung Kim ${ }^{1}$, Young-Min Lee ${ }^{1}$ \\ ${ }^{1}$ Department of Animal, Dairy, and Veterinary Sciences, Utah Science Technology and Research, College of Agriculture and Applied Sciences, Utah State University
}

Correspondence to: Young-Min Lee at youngmin.lee@usu.edu

URL: https://www.jove.com/video/53164

DOI: doi: $10.3791 / 53164$

Keywords: Immunology, Issue 106, reverse genetics, infectious cDNA, bacterial artificial chromosome, RNA virus, single-stranded, positive sense, infection, replication, pathogenesis, flavivirus, Japanese encephalitis virus

Date Published: 12/29/2015

Citation: Yun, S.I., Song, B.H., Kim, J.K., Lee, Y.M. Bacterial Artificial Chromosomes: A Functional Genomics Tool for the Study of Positive-strand RNA Viruses. J. Vis. Exp. (106), e53164, doi:10.3791/53164 (2015).

\section{Abstract}

Reverse genetics, an approach to rescue infectious virus entirely from a cloned cDNA, has revolutionized the field of positive-strand RNA viruses, whose genomes have the same polarity as cellular mRNA. The cDNA-based reverse genetics system is a seminal method that enables direct manipulation of the viral genomic RNA, thereby generating recombinant viruses for molecular and genetic studies of both viral RNA elements and gene products in viral replication and pathogenesis. It also provides a valuable platform that allows the development of genetically defined vaccines and viral vectors for the delivery of foreign genes. For many positive-strand RNA viruses such as Japanese encephalitis virus (JEV), however, the cloned cDNAs are unstable, posing a major obstacle to the construction and propagation of the functional cDNA. Here, the present report describes the strategic considerations in creating and amplifying a genetically stable full-length infectious JEV cDNA as a bacterial artificial chromosome (BAC) using the following general experimental procedures: viral RNA isolation, cDNA synthesis, cDNA subcloning and modification, assembly of a full-length cDNA, cDNA linearization, in vitro RNA synthesis, and virus recovery. This protocol provides a general methodology applicable to cloning full-length cDNA for a range of positive-strand RNA viruses, particularly those with a genome of $>10 \mathrm{~kb}$ in length, into a BAC vector, from which infectious RNAs can be transcribed in vitro with a bacteriophage RNA polymerase.

\section{Video Link}

The video component of this article can be found at https://www.jove.com/video/53164/

\section{Introduction}

For RNA virologists, the advent of recombinant DNA technology in the late 1970s made it possible to convert viral RNA genomes into cDNA clones, which could then be propagated as plasmids in bacteria for the genetic manipulation of RNA viruses. ${ }^{1}$ The first RNA virus to be molecularly cloned was bacteriophage $Q \beta$, a positive-strand RNA virus that infects Escherichia coli. A plasmid containing a complete cDNA copy of the $Q \beta$ genomic RNA gave rise to infectious $Q \beta$ phages when introduced into $E$. coli. ${ }^{2}$ Shortly thereafter, this technique was applied to poliovirus, a positive-strand RNA virus of humans and animals. A plasmid bearing a full-length cDNA of the poliovirus genomic RNA was infectious when transfected into mammalian cells and capable of producing infectious virions. ${ }^{3}$ In this "DNA-launched" approach, the cloned cDNAs should be transcribed intracellularly to initiate viral RNA replication; however, it is unclear how the transcription is initiated and how the transcripts are processed to the correct viral sequence. This concern has led to the development of an alternative "RNA-launched" approach, whereby a complete cDNA copy of the viral RNA genome is cloned under a promoter recognized by an E. coli or phage RNA polymerase for the production of synthetic RNAs in vitro with defined 5' and 3' termini, which undergo the complete viral replication cycle when introduced into host cells. ${ }^{4,5}$ The first success with this approach was reported for brome mosaic virus, ${ }^{6,7}$ a positive-strand RNA virus of plants. Since then, the RNA-launched approach has been developed for a wide range of positive-strand RNA viruses, including caliciviruses, alphaviruses, flaviviruses, arteriviruses, and coronaviruses. ${ }^{1,4,5,8}$

In both the DNA- and RNA-launched reverse genetics systems, the construction of a full-length cDNA clone is the key to generating infectious DNA or RNA of positive-strand RNA viruses, but it becomes a considerable technical challenge as the size of the viral genome increases. ${ }^{9-17}$ In particular, a large RNA genome of $\sim 10-32 \mathrm{~kb}$ presents three major obstacles to the cloning of a full-length functional cDNA. ${ }^{18}$ The first difficulty is the synthesis of a faithful cDNA copy, since the fidelity of RT-PCR is inversely proportional to the length of the viral RNA. The second hurdle is the presence of potentially toxic sequences, since long RNA molecules are more likely to contain unexpected sequences capable of making the cDNA fragment in plasmids unstable in $E$. coli. The third and most critical issue is the availability of a suitable vector, since it is difficult to find a cloning vector that can house a viral cDNA insert of $>10 \mathrm{~kb}$. Over the past three decades, these barriers have been overcome by several advances in enzymology, methodology, and vectorology. ${ }^{1,4,5,8}$ Of these, the most promising and innovative development is the cloning of large positive-strand RNA viruses as infectious bacterial artificial chromosomes (BACs). The BAC vector is a low-copy cloning plasmid (1-2 copies/cell) based on the $E$. coli fertility factor, with an average DNA insert size of $\sim 120-350 \mathrm{~kb} .{ }^{19-21}$ A DNA fragment is inserted into the BAC vector in a similar fashion to cloning into general cloning vectors; the resulting BAC clones are stable over many generations in $E$. coli. ${ }^{22,23}$ To 
date, the BAC technology has been used to create infectious cDNA clones for $>10$ members of three positive-strand RNA virus families, i.e., Flaviviridae ${ }^{24-29}$ Arteriviridae, ${ }^{30}$ and Coronaviridae. ${ }^{9,16,17,31,32}$

Using Japanese encephalitis virus (JEV) as an example, the present work reports the detailed procedures that can be used to construct a genetically stable full-length infectious BAC for a variety of positive-strand RNA viruses. JEV is a zoonotic flavivirus ${ }^{33}$ that is transmitted in nature between birds, pigs, and other vertebrate hosts by mosquito vectors. ${ }^{34,35}$ In humans, JEV infection can cause the severe often fatal neurological disease Japanese encephalitis (JE), ${ }^{36}$ which occurs in Asia and parts of the Western Pacific, ${ }^{37,38}$ with an estimated annual incidence of $\sim 50,000-175,000$ clinical cases. ${ }^{39,40}$ The genome of JEV is an $\sim 11-\mathrm{kb}$, single-stranded, positive-sense RNA molecule and consists of a single open reading frame (ORF) flanked by two non-coding regions (NCRs) at the 5 ' and $3^{\prime}$ ends. ${ }^{41,42}$ The ORF encodes a polyprotein that is cleaved by host and viral proteases to generate 10 individual proteins, designated C, prM, E, NS1, NS2A, NS2B, NS3, NS4A, NS4B, and NS5 in the N- to C-terminal direction. ${ }^{34,43,44}$ Also, an extended form of NS1 (NS1') is expressed by -1 ribosomal frameshifting at codons 8-9 of NS2A. ${ }^{45,46}$ Of these 11 proteins, the three structural proteins (C, prM, and $\mathrm{E}$ ) are essential for the formation of infectious virions, ${ }^{47,48}$ and the remaining eight nonstructural proteins (NS1 to NS5, and NS1') are crucial for viral RNA replication, ${ }^{49-51}$ particle assembly, ${ }^{52-56}$ and innate immunity evasion. ${ }^{57-59}$ Both the $5^{\prime}$ and $3^{\prime}$ NCRs contain conserved primary sequences and form RNA secondary/tertiary structures, ${ }^{60-62}$ which are important for modulating viral RNA replication. ${ }^{63,64}$

This protocol describes the tools, methods, and strategies for generating a full-length infectious BAC of JEV SA $14-14-2{ }^{28}$ This functional BAC clone contains a complete cDNA copy of the JEV genomic RNA, ${ }^{65}$ which is encompassed by a promoter for the SP6 RNA polymerase upstream of the viral 5'-end and a unique Xba I restriction site downstream of the viral 3 '-end for in vitro run-off transcription. This BAC technology is applicable to constructing a fully functional cDNA molecular clone for an array of positive-strand RNA viruses.

\section{Protocol}

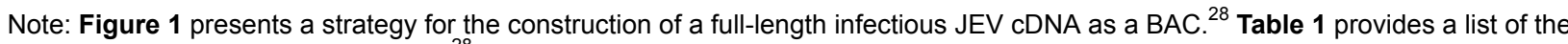
oligonucleotides used in this protocol. ${ }^{28}$

\section{Extract Viral RNA from JEV Particles in Cell Culture Supernatants}

1. Start with the cell culture medium containing JEV SA $14-14-2$, a live JE vaccine virus that requires Biosafety Level 2 containment. Note: The viral titer is approximately $1-3 \times 10^{6}$ plaque-forming units $/ \mathrm{ml}$.

2. Take the biosafety training necessary for all standard microbiological practices, safety equipment, and laboratory facilities prior to working with JEV SA $14-14-2$.

3. Purify viral RNA from an aliquot of the virus-containing cell culture medium using a monophasic solution of phenol and guanidine isothiocyanate ${ }^{66}$ (Figure 1A).

1. Add $600 \mu \mathrm{l}$ of the monophasic reagent to $200 \mu \mathrm{l}$ of the culture supernatant in a $1.7 \mathrm{ml}$ microtube. Homogenize the mixture by handshaking the tube vigorously for $30 \mathrm{sec}$ and incubating for $5 \mathrm{~min}$ at RT.

2. Add $160 \mu \mathrm{l}$ of chloroform to the homogenized sample. Mix thoroughly by hand-shaking the tube vigorously for 15 sec and leaving it for 2-3 min at RT.

3. Centrifuge the total lysate at $13,400 \times \mathrm{g}$ for $15 \mathrm{~min}$ at $4{ }^{\circ} \mathrm{C}$, which results in a separation of two liquid phases, i.e., a lower organic phase and an upper aqueous phase. Transfer the upper aqueous phase (less than $200 \mu \mathrm{l}$ ) containing the RNA to a new microtube.

4. Precipitate the RNA by adding $1 \mu \mathrm{l}$ of $5 \mu \mathrm{g} / \mu \mathrm{l}$ glycogen and $400 \mu \mathrm{l}$ of $100 \%$ isopropanol and incubating for $10 \mathrm{~min}$ at RT.

5. Centrifuge the mixture at $13,400 \times \mathrm{g}$ for $10 \mathrm{~min}$ at $4^{\circ} \mathrm{C}$. Discard the supernatant and wash the RNA pellet with $1 \mathrm{~mL}$ of $75 \%$ ethanol by pulse-vortexing three to five times and centrifuging at $13,400 \times \mathrm{g}$ for $5 \mathrm{~min}$ at $4{ }^{\circ} \mathrm{C}$.

6. Air-dry the RNA pellet for $10 \mathrm{~min}$ and dissolve it in $40 \mu \mathrm{l}$ of $\mathrm{dH}_{2} \mathrm{O}$. Store the extracted RNA at $-80{ }^{\circ} \mathrm{C}$ until use.

\section{Synthesize a Set of Four Overlapping cDNA Fragments (F1 to F4) Spanning the Entire Viral Genomic RNA by Reverse Transcription (RT)-PCR}

1. Perform a $20 \mu \mathrm{l}$ RT reaction with a $10 \mu \mathrm{l}$ aliquot of the purified viral RNA as a template and a modified form of Moloney murine leukemia virus reverse transcriptase. ${ }^{67}$

1. Set up a $13 \mu \mathrm{l}$ mixture containing $10 \mu \mathrm{l}$ of the purified RNA, $1 \mu \mathrm{l} 10 \mathrm{mM}$ dNTP mix, $1 \mu \mathrm{l} 4 \mathrm{pmol} / \mu \mathrm{l}$ primer, and $1 \mu \mathrm{ldH} \mathrm{H}_{2} \mathrm{O}$. Use the fragment-specific primer for each RT reaction: 1RT for F1, 2RT for F2, 3RT for F3, and 4RT for F4.

2. Incubate the mixture at $65{ }^{\circ} \mathrm{C}$ for $5 \mathrm{~min}$, place on ice for $1 \mathrm{~min}$, and then quick-spin to collect the contents at the bottom of the tube.

3. Add $4 \mu \mathrm{l} 5 \times \mathrm{RT}$ buffer, $1 \mu \mathrm{l} 0.1 \mathrm{M} \mathrm{DTT}, 1 \mu \mathrm{l} 40 \mathrm{U} / \mu \mathrm{l}$ RNase inhibitor, and $1 \mu \mathrm{l} 200 \mathrm{U} / \mu \mathrm{l}$ reverse transcriptase. Mix by pipetting up and down three to five times.

4. Let the reaction proceed at $50{ }^{\circ} \mathrm{C}$ for $1 \mathrm{hr}$, then heat-inactivate the sample at $70{ }^{\circ} \mathrm{C}$ for $15 \mathrm{~min}$. Store the synthesized first-strand cDNA at $-20^{\circ} \mathrm{C}$ until use.

2. Perform a $100 \mu \mathrm{l} \mathrm{PCR}$ reaction with a $5 \mu \mathrm{l}$ aliquot of the heat-inactivated RT reaction as a template and a high-fidelity thermostable DNA polymerase $^{68}$ (Figure 1B).

1. Set up a $100 \mu \mathrm{l} \mathrm{PCR}$ reaction on ice, containing $5 \mu \mathrm{l}$ of the RT reaction, $20 \mu \mathrm{l} 5 \times \mathrm{PCR}$ buffer, $4 \mu \mathrm{l} 10 \mathrm{mM}$ dNTP mix, $5 \mu \mathrm{l} 10 \mu \mathrm{M}$ forward

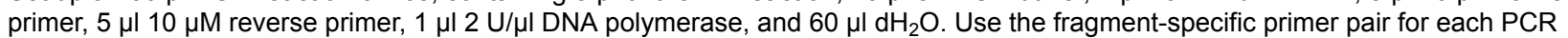
reaction: 1F+1R for F1 (2573 bp), 2F+2R for F2 (4171 bp), 3F+3R for F3 (3922 bp), and 4F+4R for F4 (1798 bp).

2. Mix gently by finger-flipping the tube three to five times and centrifuge briefly to collect its contents at the bottom.

3. Begin thermocycling with an initial denaturation step of $30 \mathrm{sec}$ at $98^{\circ} \mathrm{C}$, followed by $25-30$ cycles with the following PCR profile: 10 sec at $98^{\circ} \mathrm{C}, 30 \mathrm{sec}$ at $60^{\circ} \mathrm{C}$, and $1-2 \mathrm{~min}(30 \mathrm{~s} / \mathrm{kb})$ at $72^{\circ} \mathrm{C}$. Store the PCR products at $4{ }^{\circ} \mathrm{C}$ until analyzed. 
3. Run a $2-5 \mu \mathrm{l}$ aliquot of each $\mathrm{PCR}$ reaction on a $0.8 \%$ agarose gel containing $0.5 \mu \mathrm{g} / \mathrm{ml}$ ethidium bromide (EtBr) (Figure 2). CAUTION: EtBr is a potent mutagen and requires lab coats, safety glasses, and gloves to be worn and extreme caution to be observed during its use, storage, and disposal.

\section{Subclone Each of the Four cDNA Fragments (F1 to F4) into a BAC Vector to Create pBAC/F1 to pBAC/F4 by Molecular Cloning Techniques}

1. Digest the vector and insert DNAs with two appropriate restriction endonucleases, as follows:

1. Perform a sequential digestion of pBAC/PRRSV/FL (vector), ${ }^{30}$ a derivative of the pBeloBAC11 plasmid (7507 bp, GenBank accession number U51113), with Pme I and Not I in a total volume of $60 \mu \mathrm{l}$ (containing $500 \mathrm{ng}$ DNA, $10 \mathrm{U}$ enzyme, 1x digestion buffer, and 1x BSA) at $37^{\circ} \mathrm{C}$ for $12-15 \mathrm{hr}$, which yields the $15426-\mathrm{bp}$ vector fragment.

2. Perform a sequential digestion of each of the four CDNA amplicons (insert) with Sma I and Not I in a total volume of $60 \mu \mathrm{l}$ (containing $\sim 1 \mu \mathrm{g}$ DNA, $20 \mathrm{U}$ enzyme, $1 \times$ digestion buffer, and $1 \times \mathrm{BSA})$ at $25^{\circ} \mathrm{C}(\mathrm{Sma} \mathrm{I})$ or $37^{\circ} \mathrm{C}(\mathrm{Not} \mathrm{I})$ for $12-15 \mathrm{hr}$, which yields the following insert fragments of the desired size: F1 (2559 bp), F2 (4157 bp), F3 (3908 bp), and F4 (1784 bp).

2. Purify the desired vector and insert DNA fragments by gel extraction.

1. Separate the doubly digested products on a $1 \%$ low-melting point agarose gel containing $0.5 \mu \mathrm{g} / \mathrm{ml} \mathrm{EtBr}$. Cut out a band of the desired DNA fragment with a minimal amount of agarose (usually $\sim 200 \mu \mathrm{l}$ ) under long-wave ultraviolet light.

2. Add an equal volume of TEM buffer ( $10 \mathrm{mM}$ Tris-Cl, $1 \mathrm{mM}$ EDTA, and $10 \mathrm{mM} \mathrm{MgCl}$ ) to the excised agarose in a $1.7 \mathrm{ml} \mathrm{microtube}$ Incubate the sample at $72{ }^{\circ} \mathrm{C}$ for $10-15 \mathrm{~min}$, with vortexing every 2-3 min until the agarose has completely melted.

3. Add an equal volume of pre-warmed buffer-saturated phenol, vortex vigorously for $1 \mathrm{~min}$, and centrifuge at $13,400 \times \mathrm{g}$ for $10 \mathrm{~min}$ at RT Note: The mixture separates into a lower organic phase and an upper aqueous phase. Transfer the upper aqueous phase containing the DNA to a new microtube.

4. Add an equal volume of chloroform:isoamyl alcohol (24:1), vortex for $1 \mathrm{~min}$, and centrifuge at $13,400 \times \mathrm{g}$ for $10 \mathrm{~min}$ at RT. Transfer the upper aqueous phase to a new microtube.

5. Add $0.5 \mu \mathrm{l}$ of $10 \mu \mathrm{g} / \mu \mathrm{l}$ yeast tRNA, $1 / 10$ volume of $3 \mathrm{M}$ sodium acetate, and 2.5 volumes of $100 \%$ ethanol. Keep the mixture on ice for $20 \mathrm{~min}$.

6. Centrifuge the mixture at $13,400 \times \mathrm{g}$ for $10 \mathrm{~min}$ at RT. Remove the supernatant and wash the DNA pellet with $1 \mathrm{ml}$ of $70 \%$ ethanol by pulse-vortexing three to five times and centrifuging at $13,400 \times \mathrm{g}$ for $10 \mathrm{~min}$.

7. Air-dry the DNA pellet for $10 \mathrm{~min}$ and dissolve it in $20 \mu \mathrm{l}$ of TE buffer (10 mM Tris-Cl and $1 \mathrm{mM}$ EDTA [pH 7.6]).

3. Ligate the desired vector and insert DNA fragments using T4 DNA ligase.

1. Set up a $20 \mu$ l ligation reaction containing $50-100 \mathrm{ng}$ of the vector DNA, a $\sim 3$-fold molar excess of the insert DNA, $400 \cup$ T4 DNA ligase, and $1 \times$ ligation buffer. Incubate the ligation reaction at $16{ }^{\circ} \mathrm{C}$ for $12-15 \mathrm{hr}$. Note: Include a negative control reaction, i.e., vector only without the insert, in parallel.

2. Perform four separate ligations, each joining the 15426-bp Pme I-Not I fragment of pBAC/PRRSV/FL with the 2559-bp (for F1), 4157bp (for F2), 3908-bp (for F3), or 1784-bp (for F4) Sma I-Not I fragment of one of the four cDNA amplicons, to generate subclones $\mathrm{pBAC/F} 1$ to $\mathrm{pBAC/F} 4$.

4. Transform the ligated DNA into $E$. coli $\mathrm{DH} 10 \mathrm{~B}$ by the $\mathrm{CaCl}_{2}$-heat shock method.

1. Take $100 \mu \mathrm{l}$ aliquots of the $\mathrm{CaCl}_{2}$-treated competent $\mathrm{DH} 10 \mathrm{~B}$ cells ${ }^{69}$ stored at $-80{ }^{\circ} \mathrm{C}$ and thaw them on ice. Note: Use $100 \mu$ l of cells per transformation.

2. Add a $10 \mu \mathrm{l}$ aliquot of the DNA ligation reaction to $100 \mu \mathrm{l}$ of the thawed cells in a $1.7 \mathrm{ml}$ microtube, mix gently by tapping the tube, and keep on ice for $30 \mathrm{~min}$.

3. Heat-shock the DNA-cell mixture for $45 \mathrm{sec}$ in a $42{ }^{\circ} \mathrm{C}$ water bath, place on ice for $2 \mathrm{~min}$, and then add $900 \mu \mathrm{l}$ of LB broth pre-warmed to RT.

4. Incubate the heat-shocked cells at $35{ }^{\circ} \mathrm{C}$ for $1 \mathrm{hr}$, with shaking at $225-250 \mathrm{rpm}$.

5. Spread 50 to $200 \mu$ l aliquots of the cultured cells on LB agar plates containing $10 \mu \mathrm{g} / \mathrm{ml}$ chloramphenicol (Cml). Keep the plates at RT, right side up, until they are dry.

6. Turn the plates upside down and incubate at $35^{\circ} \mathrm{C}$ for $15 \mathrm{hr}$.

5. Recover the cloned BAC DNA from the host cells by a column-based purification method (Figure 1C).

1. Pick six to eight bacterial colonies from the LB-Cml agar plates and inoculate them into $3 \mathrm{ml}$ of $2 x Y T$ broth containing $10 \mu \mathrm{g} / \mathrm{ml} \mathrm{Cml}$. Incubate the cultures at $35^{\circ} \mathrm{C}$ for $10 \mathrm{hr}$ with vigorous shaking $(225-250 \mathrm{rpm})$.

2. Isolate recombinant BAC DNAs from $1-1.5 \mathrm{ml}$ of the bacterial cultures using spin columns, as directed by the manufacturer. ${ }^{70}$ Elute the extracted DNA (typically $100-200 \mathrm{ng}$ ) in $20 \mu$ of TE buffer.

3. Perform two analytical restriction enzyme digestions of the isolated BACs for $\sim 6 \mathrm{hr}$ in a total volume of $10 \mu \mathrm{l}$, one to identify the presence of the vector with a correct insert using the same enzymes used for cloning (see Protocol 3.1), and the other to test the integrity of the cloned BACs with an appropriate enzyme (e.g., BgI II, Nco I, or Pst I), generating a unique restriction fragment pattern.

4. Propagate the correctly cloned BACs by inoculating $500 \mu \mathrm{l}$ of the positive bacterial cultures (from Protocol 3.5 .1 ) in $500 \mathrm{ml}$ of $2 \times Y T-C \mathrm{ml}$ medium and cultivating the inoculum for $6 \mathrm{hr}$ at $35^{\circ} \mathrm{C}$ while shaking at 225-250 rpm. Purify the BAC DNA (typically 10-20 $\mu \mathrm{g}$ ) from the $500 \mathrm{ml}$ culture using filter columns, as recommended by the manufacturer. ${ }^{71}$

Note: The initial four BAC subclones, each containing a cDNA fragment of JEV genomic RNA, may prove to have one or more unwanted mutation(s) when compared to the consensus sequence of the viral genome ${ }^{42}$ (which serves as a reference sequence). Any such mutation needs to be corrected by PCR-based site-directed mutagenesis prior to the assembly of a full-length JEV cDNA. ${ }^{27}$ 


\section{Create a Full-length JEV cDNA with the 5' SP6 Promoter and the 3' Run-off Site}

1. Make three genetic modifications (see below Protocols 4.1.1-4.1.3) in the cloned cDNAs to allow in vitro run-off transcription of genomelength RNAs with the authentic 5' and 3' ends of the viral genome.

1. Introduce an SP6 promoter directly upstream of the 5' end of the viral genome by overlap extension PCR (Figure 1D, pBAC/F1 ${ }^{\text {SP6 }}$ ).

1. Amplify two overlapping DNA fragments via the first standard PCR of pBAC/F1 with the two primer pairs SP6F+SP6R (product size, $173 \mathrm{bp}$ ) and F1F+F1R (product size, $676 \mathrm{bp}$ ), each in a $50 \mu \mathrm{l}$ reaction containing $1 \mu \mathrm{l}$ template DNA $(\sim 200 \mathrm{pg} / \mu \mathrm{l}), 10 \mu \mathrm{l} 5 \times$ PCR buffer, $2 \mu \mathrm{l} 10 \mathrm{mM}$ dNTPs, $2.5 \mu \mathrm{l}$ each of $10 \mu \mathrm{M}$ forward and reverse primers, $0.5 \mu \mathrm{l} 2 \mathrm{U} / \mu \mathrm{l} \mathrm{DNA}$ polymerase, ${ }^{68}$ and $31.5 \mu \mathrm{l}$ $\mathrm{dH}_{2} \mathrm{O}$. Perform the PCR using the following cycling profile: $98^{\circ} \mathrm{C}$ for $30 \mathrm{sec}$, and 25 cycles of $98^{\circ} \mathrm{C}$ for $10 \mathrm{sec}, 60^{\circ} \mathrm{C}$ for $30 \mathrm{sec}$, and $72{ }^{\circ} \mathrm{C}$ for $20 \mathrm{sec}$.

2. Gel-purify the two PCR-amplified DNA fragments after running each of the two PCR products on a $1.5 \%$ low-melting point agarose gel, as described in Protocol 3.2.

3. Fuse the two gel-purified DNA fragments via the second fusion PCR using the outermost primers SP6F+F1R (product size, $821 \mathrm{bp})$ in a $100 \mu \mathrm{l}$ reaction including $1 \mu \mathrm{l}$ each of the two purified DNA fragments $(\sim 100 \mathrm{pg} / \mu \mathrm{l}), 20 \mu \mathrm{l} 5 \times \mathrm{PCR}$ buffer, $4 \mu \mathrm{l} 10$

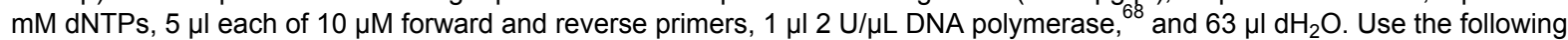
thermal cycling profile: $98^{\circ} \mathrm{C}$ for $30 \mathrm{sec}$, and 25 cycles of $98{ }^{\circ} \mathrm{C}$ for $10 \mathrm{sec}, 60^{\circ} \mathrm{C}$ for $30 \mathrm{sec}$, and $72{ }^{\circ} \mathrm{C}$ for $30 \mathrm{sec}$.

4. Gel-purify the fused PCR amplicon from a 1\% low-melting point agarose gel, as described in Protocol 3.2.

5. Perform the five-step cloning procedure described in Protocols 3.1-3.5 to ligate the 760-bp Pac I-BsiW I fragment of the gelpurified fused PCR amplicon with the 9532-bp Pac I-BsiW I fragment of pBAC/F1 to generate pBAC/F1 ${ }^{\mathrm{SP} 6}$.

2. Remove the pre-existing, internal $X b a$ I site at nucleotide 9131 by introducing a silent point mutation $\left(A^{9134} \rightarrow T\right)$ via overlap extension $\mathrm{PCR}$ (Figure 1D, pBAC/F3 ${ }^{\mathrm{KO}}$ ).

1. Amplify two overlapping DNA fragments by the first standard $P C R$ of $p B A C / F 3$ with the two primer pairs $X 1 F+X 1 R$ (product size, $746 \mathrm{bp}$ ) and $\mathrm{X} 2 \mathrm{~F}+\mathrm{X} 2 \mathrm{R}$ (product size, $316 \mathrm{bp}$ ) in a $50 \mu \mathrm{l}$ reaction under the experimental conditions described in Protocol 4.1.1.1.

2. Gel-purify the two PCR-amplified DNA fragments after electrophoretic separation on $1.5 \%$ low-melting point agarose gels, as detailed in Protocol 3.2.

3. Fuse the two gel-purified DNA fragments via the second fusion PCR using the outermost primers $\mathrm{X} 1 \mathrm{~F}+\mathrm{X} 2 \mathrm{R}$ (product size, 1033 $\mathrm{bp}$ ) in a $100 \mu \mathrm{l}$ reaction under the experimental conditions described in Protocol 4.1.1.3.

4. Gel-purify the fused PCR amplicon from a 1\% low-melting point agarose gel, as detailed in Protocol 3.2.

5. Perform the five-step cloning procedure described in Protocols 3.1-3.5 to ligate the 949-bp Avr II-Not I fragment of the gelpurified fused PCR amplicon with the 16245-bp Not I-BsiW I and 2141-bp BsiW I-Avr II fragments of pBAC/F3 to produce pBAC/ $\mathrm{F}^{\mathrm{KO}}$.

3. Engineer a new artificial Xba I run-off site just downstream of the $3^{\prime}$ end of the viral genome by PCR-based site-directed mutagenesis (Figure 1D, pBAC/F4 ${ }^{\mathrm{RO}}$ ).

1. Generate one DNA fragment by PCR of $\mathrm{pBAC} / \mathrm{F} 4$ with primers ROF+ROR (product size, $324 \mathrm{bp}$ ) in a $100 \mu \mathrm{l}$ reaction containing $1 \mu \mathrm{l}$ template DNA ( 200 pg/ $\mu \mathrm{l}), 20 \mu \mathrm{l} 5 \times$ PCR buffer, $4 \mu \mathrm{l} 10 \mathrm{mM}$ dNTPs, $5 \mu \mathrm{l}$ each of $10 \mu \mathrm{M}$ forward and reverse primers, $1 \mu \mathrm{l} 2$

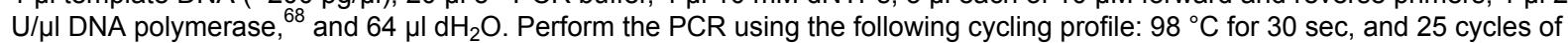
$98^{\circ} \mathrm{C}$ for $10 \mathrm{sec}, 60^{\circ} \mathrm{C}$ for $30 \mathrm{sec}$, and $72{ }^{\circ} \mathrm{C}$ for $15 \mathrm{sec}$.

2. Gel-purify the PCR-amplified DNA fragment from a $1 \%$ low-melting point agarose gel, as detailed in Protocol 3.2.

3. Perform the five-step cloning procedure described in Protocols 3.1-3.5 to ligate the 283-bp Sfi I-Not I fragment of the gel-purified PCR amplicon with the 16933-bp Sfi I-Not I fragment of pBAC/F4 to create pBAC/F4 ${ }^{\text {RO }}$.

2. Assemble a set of the four modified, overlapping cDNAs into a single full-length $S_{14}-14-2 B A C\left(p B A C / S A_{14}-14-2\right)$ by joining at three natural restriction sites (BsrG I, BamH I, and Ava I) in a sequential manner using the five-step cloning procedures detailed in Protocols 3.1-3.5 (Figure 1E): $\mathrm{F} 1^{\mathrm{SP} 6} \rightarrow \mathrm{F} 1^{\mathrm{SP} 6} \mathrm{~F} 2$ (by replacing the Bsi I-Not I fragment of pBAC/F1 ${ }^{\mathrm{SP6}}$ with that of pBAC/F2) $\rightarrow \mathrm{F} 1^{\mathrm{SP} 6} \mathrm{~F} 2 \mathrm{~F} 3^{\mathrm{KO}}$ (by replacing the $\mathrm{BamH} \mathrm{I}-\mathrm{Not} \mathrm{I}$ fragment of $\mathrm{pBAC} / \mathrm{F} 1{ }^{\mathrm{SP} 6} \mathrm{~F} 2$ with that of $\mathrm{pBAC} / \mathrm{F} 3^{\mathrm{KO}}$ ) $\rightarrow \mathrm{F} 1{ }^{\mathrm{SP} 6} \mathrm{~F} 2 \mathrm{~F} 3^{\mathrm{KO}} \mathrm{F} 4{ }^{\mathrm{RO}}$ (by replacing the Ava I-Not I fragment of pBAC/ $\mathrm{F} 1^{\mathrm{SP} 6} \mathrm{~F} 2 \mathrm{~F} 3^{\mathrm{KO}}$ with that of $\mathrm{pBAC} / \mathrm{F} 4^{\mathrm{RO}}$ ).

\section{Prepare a High-purity Maxi-prep of the Full-length $\mathrm{SA}_{14}-14-2 \mathrm{BAC}$}

1. Grow a single colony of $E$. coli $\mathrm{DH} 10 \mathrm{~B}$ carrying $\mathrm{pBAC} / \mathrm{SA}_{14}-14-2$ in $3 \mathrm{ml}$ of $2 \mathrm{xYT}$ broth containing $10 \mu \mathrm{g} / \mathrm{ml} \mathrm{Cml}$ for $10 \mathrm{hr}$ at $35^{\circ} \mathrm{C}$ with shaking at $225-250 \mathrm{rpm}$, and then scale up by inoculating $500 \mu \mathrm{l}$ of the $10 \mathrm{hr}$ bacterial culture into $500 \mathrm{ml}$ of $2 \times Y T-C m \mathrm{l}$ medium and cultivating the inoculum for $6 \mathrm{hr}$ at $35^{\circ} \mathrm{C}$ with vigorous shaking.

2. Centrifuge the bacterial culture in two $250 \mathrm{ml}$ bottles at $3,107 \times \mathrm{g}$ for $15 \mathrm{~min}$ at $4{ }^{\circ} \mathrm{C}$. Resuspend each pellet in $30 \mathrm{ml}$ of $\mathrm{GTE}$ solution $(50 \mathrm{mM}$ glucose, $25 \mathrm{mM}$ Tris-Cl, and $10 \mathrm{mM}$ EDTA [pH 8.0]), and then add $500 \mu \mathrm{l}$ of $60 \mathrm{mg} / \mathrm{ml}$ lysozyme. Incubate the two cell suspensions on ice for $10 \mathrm{~min}$.

3. Add $60 \mathrm{ml}$ of freshly made Lysis solution $(0.2 \mathrm{~N} \mathrm{NaOH}$ and $1 \%$ SDS) to each cell suspension, mix well until clear, and keep the lysates at RT for $10 \mathrm{~min}$.

4. Add $45 \mathrm{ml}$ of Neutralization solution ( $100 \mathrm{ml}$, consisting of $60 \mathrm{ml} 5 \mathrm{M}$ potassium acetate, $11.5 \mathrm{ml}$ glacial acetic acid, and $28.5 \mathrm{ml} \mathrm{dH_{2 }} \mathrm{O}$ ) to each bottle, mix thoroughly by inverting the bottles, and incubate the neutralized lysates on ice for $10 \mathrm{~min}$.

5. Centrifuge the neutralized lysates at $18,566 \times \mathrm{g}$ for $20 \mathrm{~min}$ at $4{ }^{\circ} \mathrm{C}$. Transfer the supernatant of both bottles into two new $250 \mathrm{ml}$ bottles; add 0.6 volume of $100 \%$ isopropanol to each, and keep them on ice for $20 \mathrm{~min}$

6. Spin down the precipitates at $18,566 \times \mathrm{g}$ for $20 \mathrm{~min}$ at $4{ }^{\circ} \mathrm{C}$. Dissolve each pellet in $5 \mathrm{ml}$ of TE buffer, combine them in a $50 \mathrm{ml}$ tube $(10 \mathrm{ml}$ total), and precipitate the RNA by adding an equal volume of $5 \mathrm{M}$ lithium chloride. Incubate the mixture on ice for $10 \mathrm{~min}$.

7. Centrifuge the RNA precipitate at $14,636 \times \mathrm{g}$ for $20 \mathrm{~min}$ at $4{ }^{\circ} \mathrm{C}$. Transfer the supernatant to a new $250 \mathrm{ml}$ tube and precipitate DNA by adding 2 volumes of $100 \%$ isopropanol. Incubate the mixture on ice for $20 \mathrm{~min}$. 
8. Spin down the DNA precipitate at $18,566 \times \mathrm{g}$ for $20 \mathrm{~min}$ at $4{ }^{\circ} \mathrm{C}$. Aspirate the supernatant, resuspend the DNA pellet in $9.5 \mathrm{ml}$ of TE buffer (pH 7.6), and add $10 \mathrm{~g}$ of cesium chloride ( $\mathrm{CsCl}$ ) and $390 \mu \mathrm{l}$ of $10 \mathrm{mg} / \mathrm{ml} \mathrm{EtBr}$.

9. Load the DNA-CsCl-EtBr solution into a $16 \times 76 \mathrm{~mm}$ sealable polypropylene tube using a syringe equipped with an $18 \mathrm{G}$ needle. Spin the sealed $\mathrm{CsCl}$ gradient in an ultracentrifuge at $401,700 \times \mathrm{g}$ for $16 \mathrm{hr}$ at $20^{\circ} \mathrm{C}$ (Figure 3).

10. Collect a DNA band of $\mathrm{BAC}$ plasmid from the $\mathrm{CsCl}$ gradient using an $18 \mathrm{G}$ needle to create an air vent at the top of the gradient and a $20 \mathrm{G}$ needle-equipped syringe to retrieve the BAC DNA from the side of the gradient.

11. Add 2.5 volumes of $\mathrm{dH}_{2} \mathrm{O}$-saturated butanol to the $\mathrm{EtBr}$-stained $\mathrm{BAC}$ DNA sample and mix by vortexing. Centrifuge the mixture at $13,400 \times \mathrm{g}$ for $1 \mathrm{~min}$ and transfer the lower aqueous phase to a new $1.7 \mathrm{ml}$ microtube. Repeat this procedure six times.

12. Precipitate the EtBr-free BAC DNA by adding $1 / 10$ volume of $3 \mathrm{M}$ sodium acetate and 2.5 volumes of $100 \%$ ethanol to the butanol-extracted BAC DNA and incubating for $10 \mathrm{~min}$ on ice. Centrifuge the precipitate at $13,400 \times \mathrm{g}$ for $10 \mathrm{~min}$, wash the DNA pellet with $1 \mathrm{ml}$ of $70 \%$ ethanol, and re-pellet it by centrifugation.

13. Air-dry the DNA pellet for $10 \mathrm{~min}$ and dissolve it in $200 \mu \mathrm{l}$ of TE buffer $(\mathrm{pH} 7.6)$. Note: Figure 4 shows an overview of the reverse genetics system for JEV SA $14-14-2$.

\section{Transcribe Synthetic RNAs In Vitro from a Linearized Full-length JEV BAC DNA}

1. Perform a large-scale restriction enzyme digestion of $\mathrm{pBAC} \mathrm{SA}_{14}-14-2$ with $\mathrm{Xba}$ I in a total volume of $100 \mu \mathrm{l}$ (containing $3 \mu \mathrm{g}$ DNA, $60 \mathrm{U}$ enzyme, $1 \times$ digestion buffer, and $1 \times \mathrm{BSA}$ ) at $37^{\circ} \mathrm{C}$ for $12-15 \mathrm{hr}$. Examine a $3 \mu \mathrm{l}$ aliquot of the digestion reaction on a $0.8 \%$ agarose gel containing $0.5 \mu \mathrm{g} / \mathrm{ml} \mathrm{EtBr}$.

2. Incubate the digestion reaction further with $25 \mathrm{U}$ of mung bean nuclease (MBN) at $30^{\circ} \mathrm{C}$ for $2 \mathrm{hr}$ (Figure 4A).

3. Bring the volume of the Xba l-digested, MBN-treated sample up to $300 \mu$ with $\mathrm{dH}_{2} \mathrm{O}$. Add an equal volume of phenol:chloroform:isoamyl alcohol (25:24:1) to the diluted sample, vortex vigorously for $1 \mathrm{~min}$, spin at $13,400 \times \mathrm{g}$ for $10 \mathrm{~min}$, and then transfer the upper aqueous phase to a new $1.7 \mathrm{ml}$ microtube. Add an equal volume of chloroform and repeat the extraction procedure.

4. Recover the phenol/chloroform-extracted, linearized BAC by ethanol precipitation: Add $1 / 10$ volume of $3 \mathrm{M}$ sodium acetate and 2.5 volumes of $100 \%$ ethanol, and incubate on ice for $20 \mathrm{~min}$. Centrifuge the precipitate at $13,400 \times \mathrm{g}$ for $10 \mathrm{~min}$, wash the DNA pellet with $1 \mathrm{ml}$ of $70 \%$ ethanol, and then spin it down by re-centrifugation.

5. Air-dry the DNA pellet for 10 min and dissolve it in $30 \mu \mathrm{l}$ of $\mathrm{dH}_{2} \mathrm{O}$. Examine a $1 \mu \mathrm{l}$ aliquot of the recovered $\mathrm{BAC}$ on a $0.8 \%$ agarose gel with $0.5 \mu \mathrm{g} / \mathrm{ml} \mathrm{EtBr}$ (Figure 5A).

6. Perform a run-off transcription of the linearized BAC DNA in a total volume of $25 \mu \mathrm{l}$ (containing $\sim 200 \mathrm{ng}$ template DNA, $0.8 \mathrm{mM}$ cap analog $\left[\mathrm{m}^{7} \mathrm{G}\left(5^{\prime}\right) \mathrm{ppp}\left(5^{\prime}\right) \mathrm{A}\right], 1 \mathrm{mM}$ rNTPs, $40 \cup$ RNase inhibitor, $20 \mathrm{U}$ SP6 RNA polymerase, ${ }^{72}$ and $1 \times$ transcription buffer) at $37^{\circ} \mathrm{C}$ for $1 \mathrm{hr}($ Figure 4B). Include $0.5 \mu \mathrm{M}\left[{ }^{3} \mathrm{H}\right] \mathrm{UTP}$ for RNA quantification on the basis of $\left[{ }^{3} \mathrm{H}\right] \mathrm{UTP}$ incorporation, as monitored by adsorption to DE-81 filter paper. ${ }^{69}$

7. Run a $1-2 \mu \mathrm{l}$ aliquot of the run-off transcription reaction on a $0.6 \%$ agarose gel containing $0.5 \mu \mathrm{g} / \mathrm{ml} \mathrm{EtBr}$ (Figure 5B).

\section{Determine RNA Infectivity and Virus Yield}

1. Cultivate BHK-21 cells in $150 \mathrm{~mm}$ culture dishes at a density of $3 \times 10^{6}$ cells/dish for $24 \mathrm{hr}$ at $37{ }^{\circ} \mathrm{C}$ with $5 \% \mathrm{CO}_{2}$. Note: Maintain the BHK-21 cells in alpha minimal essential medium supplemented with $10 \%$ fetal bovine serum, 2 mM glutamine, vitamins, and penicillin/streptomycin.

2. Rinse the cell monolayer with $10 \mathrm{ml}$ of cold Solution $\mathrm{A}\left(137 \mathrm{mM} \mathrm{NaCl}, 2.7 \mathrm{mM} \mathrm{KCl}, 8.1 \mathrm{mM} \mathrm{Na}_{2} \mathrm{HPO}_{4}\right.$, and $1.5 \mathrm{mM} \mathrm{KH}_{2} \mathrm{PO}_{4}$ ). Detach the cells from the dishes by treatment with $4 \mathrm{ml}$ of trypsin-EDTA $(0.25 \%)$, and collect them by centrifugation at $270 \times \mathrm{g}$ in a desktop centrifuge for 2 $\min$.

3. Resuspend the cell pellet with $50 \mathrm{ml}$ of cold Solution $\mathrm{A}$ in a $50 \mathrm{ml}$ conical tube and centrifuge the cell suspension at $270 \times \mathrm{g}$ for $2 \mathrm{~min}$. Repeat this wash procedure three times; after the last wash, resuspend the cell pellet at a density of $2 \times 10^{7}$ cells $/ \mathrm{ml}$ in Sol A.

4. Mix a $400 \mu \mathrm{l}$ aliquot of cell suspension with $2 \mu \mathrm{g}$ of synthetic RNA in a 2-mm gap cuvette, and promptly electroporate the mixture with an electroporator under optimal electroporation conditions: $980 \mathrm{~V}, 99 \mu \mathrm{sec}$ pulse length, and 5 pulses (Figure 4C). Note: Use the ${ }^{3} \mathrm{H}$-labeled RNA synthesized in Protocol 6.5 directly for electroporation without further purification.

5. Leave the electroporated cells at RT for $10 \mathrm{~min}$ and transfer to a $1.7 \mathrm{ml}$ microtube containing $600 \mu \mathrm{l}$ of complete culture medium.

6. Prepare a 10 -fold serial dilution of the electroporated cells in $1 \mathrm{ml}$ of complete culture medium and plate a $100 \mu \mathrm{l}$ aliquot of each dilution on the monolayers of unelectroporated BHK-21 cells $\left(5 \times 10^{5}\right)$ in a 6-well plate.

7. After $4-6 \mathrm{hr}$ of incubation, overlay the cells with $0.5 \%$ agarose in minimal essential medium containing $10 \%$ fetal bovine serum. Incubate the plates for 4 days at $37^{\circ} \mathrm{C}$ with $5 \% \mathrm{CO}_{2}$.

8. Visualize the infectious centers (plaques) by fixation with $7 \%$ formaldehyde and staining with $1 \%$ crystal violet in $5 \%$ ethanol ${ }^{27}$ (Figure $6 \mathbf{A}$ ).

1. Optional: Examine RNA-electroporated cells at $18-20 \mathrm{hr}$ post-transfection for JEV protein expression by immunofluorescence assays $^{27,73}$ (Figure 6B), and harvest the supernatants from the RNA-electroporated cells at 22 and 40 hr post-transfection for virus titration by plaque assays ${ }^{27,63}$ (Figure 6C). 


\section{Representative Results}

For all positive-strand RNA viruses, the reliability and efficiency of a reverse genetics system depend on the genetic stability of a cloned fulllength CDNA, whose sequence is equivalent to the consensus sequence of viral genomic RNA. ${ }^{27}$ Figure 1 shows a five-step strategy for the construction of a full-length infectious CDNA as a BAC for JEV SA $14-14-2^{28}$ : Step 1, purification of viral RNA from the cell culture supernatant of JEV-infected BHK-21 cells (Figure 1A); Step 2, synthesis of four overlapping cDNA amplicons (F1 to F4) spanning the whole viral genome (Figure 1B); Step 3, subcloning of each of the four contiguous cDNA fragments into a BAC vector, creating pBAC/F1 to pBAC/F4 (Figure 1C); Step 4, modification of the cloned cDNAs for in vitro run-off transcription with SP6 RNA polymerase, i.e., placing an SP6 promoter sequence immediately upstream of the viral $5^{\prime}$-end $\left(\mathrm{pBAC} / \mathrm{F} 1^{\mathrm{SP} 6}\right.$ ), eliminating a pre-existing internal $X b a$ I site at nucleotide 9131 by introducing a silent point mutation, $A^{9134} \rightarrow T\left(p B A C / F 3^{K O}\right)$, and inserting a new artificial $X b a$ I run-off site immediately downstream of the viral $3^{\prime}-e n d\left(p B A C / F 4^{R O}\right.$ ) (Figure 1D); and Step 5, assembly of a full-length $\mathrm{SA}_{14}-14-2 \mathrm{cDNA} B A C, \mathrm{pBAC} / \mathrm{SA}_{14}-14-2$ (Figure 1E). Table 1 lists the oligonucleotides used in this cloning procedure. ${ }^{28}$

For the construction of a functional JEV cDNA, the first important step is the synthesis of the four overlapping cDNA fragments using the purified viral RNA as a template for RT-PCR. Figure 2 provides a representative result for the four RT-PCR products that were electrophoresed on a $0.8 \%$ agarose gel. This gel demonstrates clearly that a full-length JEV cDNA is amplified into four overlapping cDNA fragments. Occasionally, RT-PCR reactions might yield one or more additional virus-specific or nonspecific products that are mostly smaller than the expected product, because of the nonspecific annealing of primers during cDNA synthesis/amplification. On the other hand, little or no expected RT-PCR product would be amplified because of accidental RNase contamination during the viral RNA isolation or improper RT-PCR performance.

The next key step is the cloning and modification of a partial- or full-length JEV cDNA in BAC, which is a relatively straightforward procedure that uses standard recombinant DNA techniques. ${ }^{69}$ Figure 3 presents a representative outcome for the purification of the BAC clone containing a fulllength cDNA of JEV SA $14-14-2$ by banding in a CsCl-EtBr gradient. In this experiment, after centrifugation for $16 \mathrm{hr}$ at $401,700 \times \mathrm{g}$, two distinct bands, i.e., the E. coli chromosomal DNA above and the supercoiled BAC plasmid DNA below, are visible in the middle of the tube under longwave ultraviolet light. A minimal volume $(\sim 400 \mu \mathrm{l})$ of the lower BAC DNA band was carefully collected by poking a hole with a syringe on the side of the tube. Subsequently, the EtBr was extracted from the BAC DNA by butanol extraction, and the EtBr-free BAC DNA was concentrated by ethanol precipitation.

The final step is the determination of the specific infectivity of the synthetic RNAs transcribed in vitro from the full-length SA $14-14-2$ BAC (pBAC/ $\mathrm{SA}_{14}$-14-2) after RNA transfection into permissive cells (Figure 4). This step involves three sequential steps: Step 1, linearization of the fulllength $\mathrm{SA}_{14}-14-2 \mathrm{cDNA}$ at the 3'-end of the viral genome (Figure 4A); Step 2, production of synthetic RNAs from the linearized cDNA by runoff transcription (Figure 4B); and Step 3, rescue of the recombinant viruses in BHK-21 cells transfected with the synthetic RNAs (Figure 4C). Experimentally, two independent clones of $\mathrm{pBAC}_{\mathrm{SA}} \mathrm{A}_{14}-14-2$ were linearized with $\mathrm{Xba}$ I digestion and treated with $\mathrm{MBN}$ to remove the fourbase 5 ' overhang generated by the $\mathrm{Xba} I$ digestion. The linearized BACs were cleaned up by phenol-chloroform extraction, followed by ethanol precipitation. The linearization of the two purified BACs was demonstrated on a $0.8 \%$ agarose gel (Figure 5A). The phenol-chloroform extraction must be done carefully to ensure that the linearized BACs are RNase-free. Each of the two linearized BACs served as a cDNA template for runoff transcription using SP6 RNA polymerase in the presence of the $\mathrm{m}^{7} \mathrm{G}\left(5^{\prime}\right) \mathrm{ppp}\left(5^{\prime}\right) \mathrm{A}$ cap analog. The integrity of the synthetic RNAs was shown by running aliquots of the two transcription reaction mixtures on a $0.6 \%$ agarose gel, along with a reference $1 \mathrm{~kb}$ DNA ladder (Figure 5B). In this simple assay, the major prominent RNA band always migrated just below the $3 \mathrm{~kb}$ reference DNA band and appeared to be sharp. However, degraded RNA would have a smeared appearance on the same gel.

An infectious center assay is the gold standard for determining the specific infectivity of the synthetic RNAs. This assay was done by electroporating BHK-21 cells with RNA samples, seeding equal aliquots of the 10-fold serially diluted electroporated cells in 6-well plates containing naïve BHK-21 cells $\left(3 \times 10^{5}\right.$ cells/well), and overlaying agarose onto the cell monolayers. After incubation for 4 days, surviving cells were fixed with formaldehyde and stained with a crystal violet solution to quantify the number of infectious centers (plaques), which corresponds to the number of infectious RNA molecules delivered into the cells (Figure 6A). Since the cDNA template used for in vitro transcription has been proven to be non-infectious, ${ }^{27}$ an aliquot of the transcription reaction mixture was directly used for electroporation. Electroporation is the preferred method for RNA transfection; alternatively, RNAs can be transfected by other methods using DEAE-dextran and cationic liposomes. RNA electroporation is very effective, but "arcing" of the electric pulse occurs rarely if salts are present in the electroporation reaction or if the electroporation cuvette is reused. The expression of viral proteins in RNA-transfected cells was examined by immunofluorescence assays using an anti-NS1 rabbit antiserum (Figure 6B). The production of viral particles accumulated in the supernatants of RNA-transfected cells was analyzed by plaque assays (Figure $\mathbf{6 C}$ ). The results of these experiments show clearly that the cDNA-derived synthetic RNAs are infectious in permissive BHK-21 cells, generating a high titer of recombinant viruses. 


\begin{tabular}{|c|c|c|c|}
\hline Oligonucleotide & Sequence $^{\mathrm{a}}\left(5^{\prime}\right.$ to $\left.3^{\prime}\right)$ & Position $^{b}$ & Polarity \\
\hline 1RT & $\begin{array}{l}\text { TAGGGATCTGGGCGTTTCTG } \\
\text { GCAAAT }\end{array}$ & 2578-2603 & Antisense \\
\hline $1 \mathrm{~F}$ & $\begin{array}{l}\text { aatcccgggAGAAGTTTATC } \\
\text { TGTGTGAACTT }\end{array}$ & $1-22$ & Sense \\
\hline $1 \mathrm{R}$ & $\begin{array}{l}\text { attgcggccgcCCACGTCGT } \\
\text { TGTGCACGAAGAT }\end{array}$ & $2532-2553$ & Antisense \\
\hline $2 \mathrm{RT}$ & $\begin{array}{l}\text { TTCTGCCTACTCTGCCCCTC } \\
\text { CGTTGA }\end{array}$ & $5975-6000$ & Antisense \\
\hline $2 \mathrm{~F}$ & $\begin{array}{l}\text { aatcccgggTCAAGCTCAGT } \\
\text { GATGTTAACAT }\end{array}$ & $1800-1821$ & Sense \\
\hline $2 \mathrm{R}$ & $\begin{array}{l}\text { attgcggccgcGATGGGTTT } \\
\text { CCGAGGATGACTC }\end{array}$ & $5929-5950$ & Antisense \\
\hline $3 \mathrm{RT}$ & $\begin{array}{l}\text { ACGGTCTTTCCTTCTGCTGC } \\
\text { AGGTCT }\end{array}$ & $9426-9451$ & Antisense \\
\hline $3 F$ & $\begin{array}{l}\text { aatcccgggGAGGATACATT } \\
\text { GCTACCAAGGT }\end{array}$ & $5500-5521$ & Sense \\
\hline $3 R$ & $\begin{array}{l}\text { attgcggccgcGTAAGTCAG } \\
\text { TTCAATTATGGCT }\end{array}$ & 9380-9401 & Antisense \\
\hline $4 \mathrm{RT}$ & $\begin{array}{l}\text { AGATCCTGTGTTCTTCCTCA } \\
\text { CCACCA }\end{array}$ & 10952-10977 & Antisense \\
\hline $4 \mathrm{~F}$ & $\begin{array}{l}\text { aatcccgggAGTGGAAGGCT } \\
\text { CAGGCGTCCAA }\end{array}$ & $9200-9221$ & Sense \\
\hline $4 \mathrm{R}$ & $\begin{array}{l}\text { attgcggccgcAGATCCTGT } \\
\text { GTTCTTCCTCACC }\end{array}$ & $10956-10977$ & Antisense \\
\hline SP6F & $\begin{array}{l}\text { cataccccgcgtattcccac } \\
\text { ta }\end{array}$ & & Sense \\
\hline SP6R & $\begin{array}{l}\text { ACAGATAAACTTCTctatag } \\
\text { tgtcccctaaa }\end{array}$ & $1-14$ & Antisense \\
\hline F1F & $\begin{array}{l}\text { aggggacactatagAGAAGT } \\
\text { TTATCTGTGTG }\end{array}$ & $1-17$ & Sense \\
\hline F1R & $\begin{array}{l}\text { TGGATCATTGCCCATGGTAA } \\
\text { GCTTA }\end{array}$ & $638-662$ & Antisense \\
\hline $\mathrm{X} 1 \mathrm{~F}$ & $\begin{array}{l}\text { CGAATGGATCGCACAGTGTG } \\
\text { GAGAG }\end{array}$ & $8403-8427$ & Sense \\
\hline $\mathrm{X} 1 \mathrm{R}$ & $\begin{array}{l}\text { AAAGCTTCAAACTCAAGATA } \\
\text { CCGTGCTCC }\end{array}$ & $9120-9148$ & Antisense \\
\hline $\mathrm{X} 2 \mathrm{~F}$ & $\begin{array}{l}\text { GGAGCACGGTATCTTGAGTT } \\
\text { TGAAGCTTT }\end{array}$ & $9120-9148$ & Sense \\
\hline $\mathrm{X} 2 \mathrm{R}$ & $\begin{array}{l}\text { cacgtggacgagggcatgcc } \\
\text { tgcag }\end{array}$ & & Antisense \\
\hline ROF & $\begin{array}{l}\text { CCAGGAGGACTGGGTTACCA } \\
\text { AAGCC }\end{array}$ & $10670-10694$ & Sense \\
\hline ROR & $\begin{array}{l}\text { agggcggccgctctagAGAT } \\
\text { CCTGTGTTCTTCCTCACCAC }\end{array}$ & 10954-10977 & Antisense \\
\hline
\end{tabular}

Table 1: Oligonucleotides used for cDNA synthesis, PCR amplification, and BAC mutagenesis. 


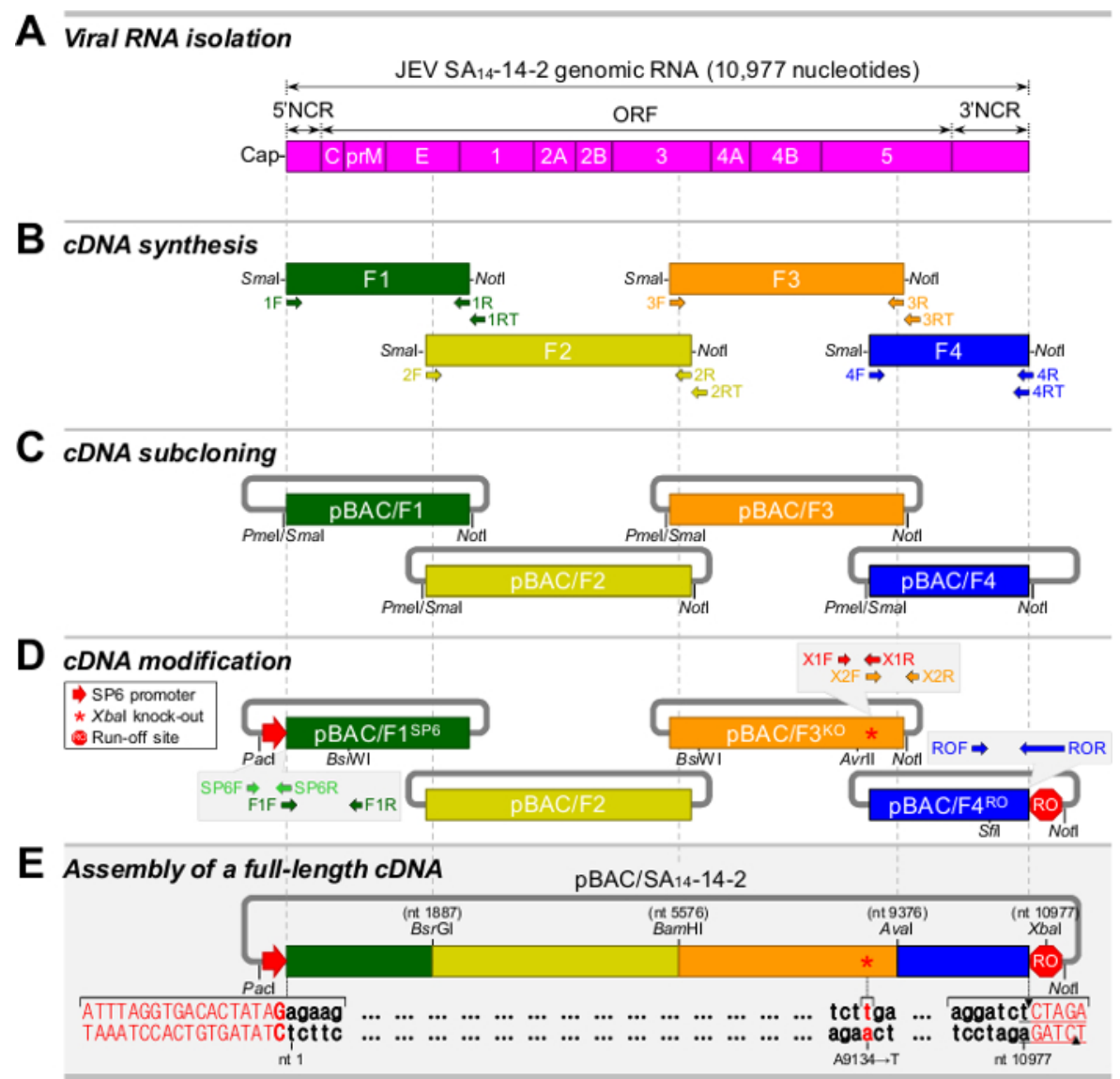

Figure 1. Strategy for the construction of a full-length cDNA of JEV SA $14-14-2$ as a BAC. (A) Isolation of viral RNA from JEV particles. Shown is a schematic diagram of the genomic RNA of JEV SA $14-14-2$. (B) Synthesis of four overlapping cDNA fragments (F1 to F4) covering the entire viral genome. (C) Subcloning of four overlapping CDNA fragments into a BAC vector, creating pBAC/F1 to pBAC/F4. (D) Modification of the cloned cDNAs for run-off transcription in vitro. $\mathrm{pBAC} / \mathrm{F} 1^{\mathrm{SP} 6}$ is a derivative of $\mathrm{pBAC} / \mathrm{F} 1$ that contains the SP6 promoter sequence upstream of the viral $5^{\prime}$-end. $\mathrm{pBAC} / \mathrm{F} 3^{\mathrm{KO}}$ is a derivative of $\mathrm{pBAC} / \mathrm{F} 3$ that contains a silent point mutation $\left(\mathrm{A}^{9134} \rightarrow \mathrm{T}\right.$, asterisk). $\mathrm{pBAC} / \mathrm{F} 4^{\mathrm{RO}}$ is a derivative of $\mathrm{pBAC} /$

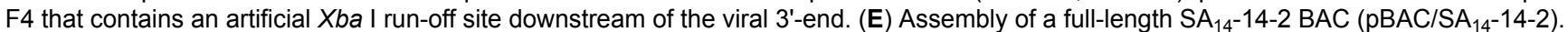
Please click here to view a larger version of this figure. 


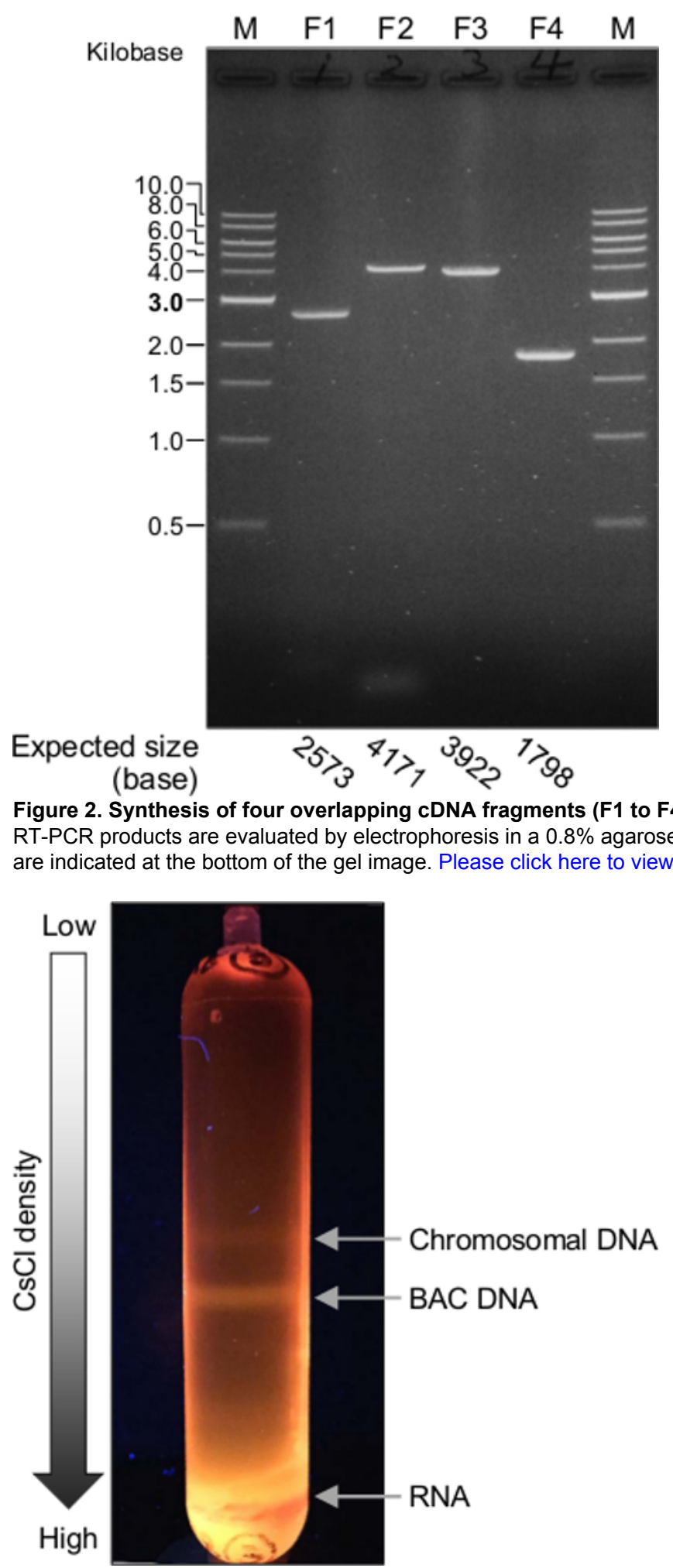

Figure 3. Purification of the BAC containing a full-length cDNA of JEV SA $\mathbf{1 4}_{\mathbf{1}} \mathbf{- 1 4 - 2}$. The BAC plasmid is isolated from $E$. coli DH10B by the SDS-alkaline lysis method and further purified by banding in a $\mathrm{CsCl}-\mathrm{EtBr}$ gradient. Presented is an example of the $\mathrm{CsCl}-\mathrm{EtBr}$ gradient using a 16 $\times 76 \mathrm{~mm}$ sealable polypropylene tube. Please click here to view a larger version of this figure. 


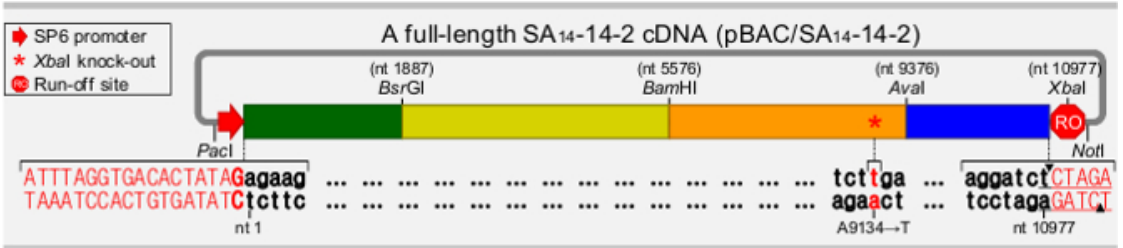

A cDNA linearization (Xbal \& MBN treatment)

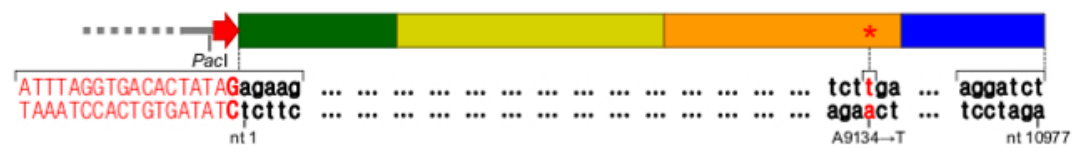

B In vitro RNA synthesis (SP6 RNA Pol run-off transcription)

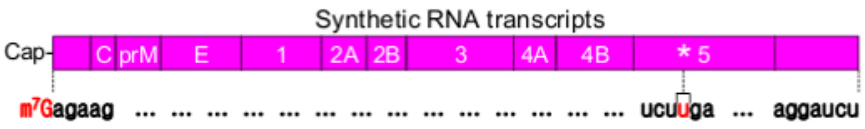

\section{Virus recovery (RNA transfection)}

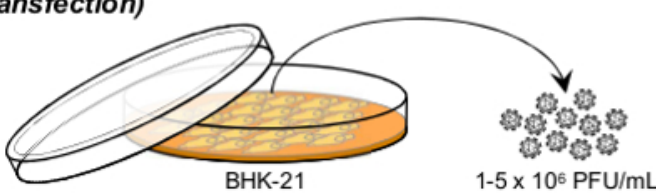

Figure 4. Overview of the recovery of infectious viruses from a full-length JEV SA $14-14-2$ cDNA assembled in a BAC. (A) Linearization of the cDNA template. The full-length JEV BAC is cut with Xba I and treated with MBN. (B) Synthesis of the RNA transcripts. The linearized cDNA is transcribed by SP6 RNA polymerase in the presence of the $\mathrm{m}^{7} \mathrm{G}\left(5^{\prime}\right) \mathrm{ppp}\left(5^{\prime}\right) \mathrm{A}$ cap analog. (C) Recovery of the synthetic JEVs. The in vitro transcribed RNAs are transfected into BHK-21 cells by electroporation, which generates a high titer of synthetic virus. Please click here to view a larger version of this figure.

A

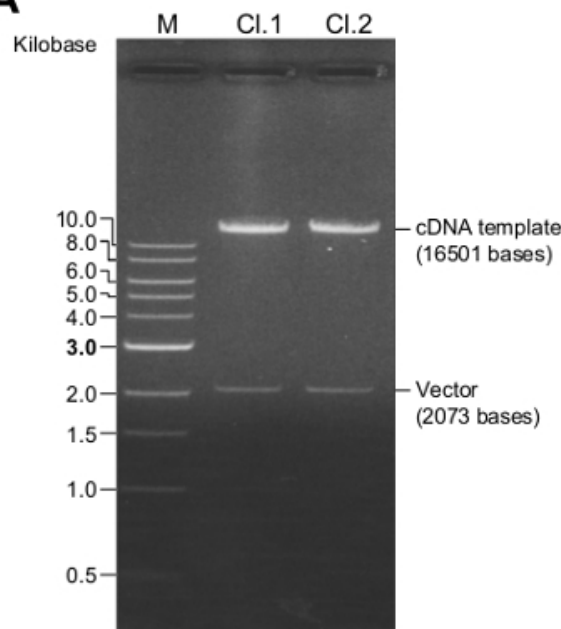

B

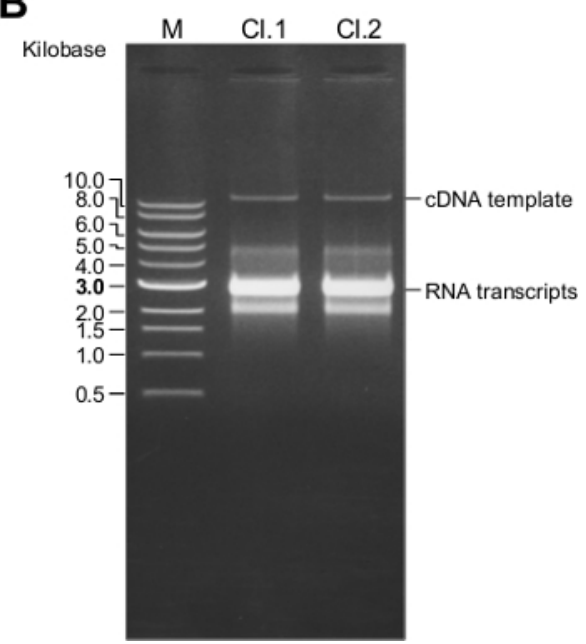

Figure 5. Synthesis of the RNAs by in vitro transcription using a full-length JEV BAC as a cDNA template. (A) Generation of the linearized full-length JEV BAC, pBAC/SA $14-14-2$. Two independent clones of $\mathrm{pBAC} / \mathrm{SA}_{14}-14-2(\mathrm{Cl} .1$ and $\mathrm{Cl}$.2) are linearized by digestion with $X b a$ I and subsequent treatment with MBN. The linearized BACs are examined by electrophoresis in a $0.8 \%$ agarose gel. (B) Production of the synthetic RNAs by run-off transcription. Each of the two linearized BACs is used as a template for SP6 RNA polymerase run-off transcription. Aliquots of the two transcription reactions are run on a $0.6 \%$ agarose gel. $\mathrm{M}, 1 \mathrm{~kb}$ DNA ladder. Please click here to view a larger version of this figure. 
A

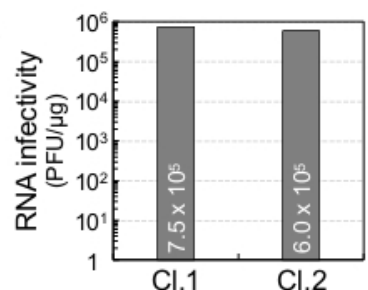

B

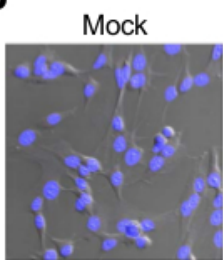

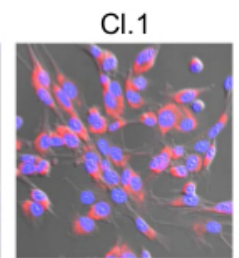
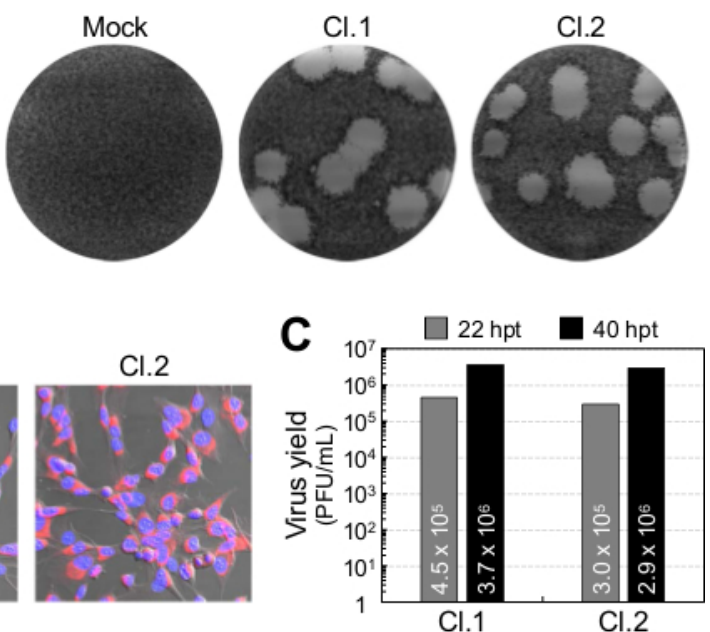

Figure 6. Specific infectivity of the synthetic RNAs transcribed from a full-length JEV BAC and the recovery of synthetic virus. BHK-21 cells are mock-electroporated (Mock) or electroporated with the RNA transcripts derived from each of the two independent clones of the fulllength JEV BAC (Cl.1 and Cl.2). (A) RNA infectivity. The cells are overlaid with agarose and stained with crystal violet at 4 days post-transfection RNA infectivity is determined by infectious center assays to estimate the amount of infectious RNA electroporated into the cells (left panel). Also, representative images of infectious centers are shown (right panel). (B) Protein expression. The cells are cultured in 4-well chamber slides. Viral protein expression in RNA-electroporated cells at $20 \mathrm{hr}$ post-transfection (hpt) is analyzed by immunofluorescence assays using a primary anti-NS1 rabbit antiserum and a secondary Cy3-conjugated goat anti-rabbit IgG (red). The nuclei are counterstained with 4',6-diamidino-2phenylindole (blue). The immunofluorescence images are overlaid on their corresponding differential interference contrast images. (C) Virus yield. The cells are cultured in $150 \mathrm{~mm}$ culture dishes. The production of infectious virions accumulated in the culture supernatants of RNAelectroporated cells at 22 and $40 \mathrm{hpt}$ is examined by plaque assays. Please click here to view a larger version of this figure.

\section{Discussion}

The current protocol has been successfully used to generate full-length infectious cDNA clones for two different strains (CNU/LP2 ${ }^{27}$ and $\mathrm{SA}_{14}-14-2^{28}$ ) of JEV, a flavivirus whose functional cDNA has proved to be inherently difficult to construct and propagate because of host cell toxicity and the genetic instability of the cloned cDNA.,74-76 This protocol involves three major components: first, maximizing the synthesis/ amplification of a faithful cDNA copy of the viral RNA using high-fidelity reverse transcriptase/DNA polymerase; second, cloning the viral prM-E coding region containing toxic sequences (unpublished data) ${ }^{74,77,78}$ in a very low-copy number vector BAC from the initial cDNA subcloning to the final full-length cDNA assembly steps; and third, utilizing a cloning vector BAC that can accommodate a foreign DNA with an average size of $120-350 \mathrm{~kb},{ }^{19-21}$ which apparently tolerates larger DNA inserts than do other cloning vectors. This cloning approach will be generally applicable to many other positive-strand RNA viruses, particularly those with a large RNA genome of $\sim 10$ to $32 \mathrm{~kb}$. Generation of an infectious cDNA clone is a key step in developing a reverse genetics system for RNA viruses, especially for positive-strand RNA viruses, because its genome acts as viral mRNA that is translated into proteins by host cell ribosomes. Thus, viral replication can be initiated by the introduction of a cDNA-derived genome-length RNA molecule into a susceptible host cell. The availability of an infectious JEV cDNA clone, when combined with recombinant DNA technology, has increased our understanding of various aspects of the viral life cycle at the molecular level, such as gene expression ${ }^{73,79}$ and genome replication. ${ }^{63,64}$ Also, a full-length JEV cDNA clone has proven to be a valuable tool for the development of antiviral vaccines ${ }^{28}$ and gene delivery vectors. ${ }^{80,81}$

As with all positive-strand RNA viruses, there are multiple critical steps in constructing a reliable functional cDNA for JEV from which highly infectious RNAs can be synthesized in vitro. Ideally, the sequence of the synthetic RNAs transcribed from a clone of the full-length cDNA should be identical to that of the viral genomic RNA, particularly the 5'- and 3'-terminal sequences that are required for the initiation of viral RNA replication. ${ }^{60-62}$ In the current protocol, the authentic 5'- and 3'-ends were ensured by placing the SP6 promoter sequence upstream of the first adenine nucleotide of the viral genome and positioning a unique artificial $X b a$ I restriction site downstream of the last thymine nucleotide of the viral genome, respectively. Capped synthetic RNAs with the authentic $5^{\prime}$ and $3^{\prime}$ ends were produced by run-off transcription of an Xba I-linearized and MBN-treated cDNA template using SP6 RNA polymerase primed with the $\mathrm{m}^{7} \mathrm{G}\left(5^{\prime}\right) \mathrm{ppp}\left(5^{\prime}\right) \mathrm{A}$ cap analog. This protocol can be modified in several ways. For in vitro transcription, another bacteriophage RNA polymerase (e.g., T3 or T7) can be used in conjunction with its well-defined promoter sequence. ${ }^{27}$ As a run-off site, a different restriction site can be utilized if it is not present in the viral genome and if synthetic RNA from the linearized cDNA ends with the authentic 3' end. The importance of the 3'-end nucleotide sequence has been demonstrated by a $\sim 10$-fold decrease in RNA infectivity when a synthetic RNA contains three or four virus-unrelated nucleotides at its $3^{\prime}$ end. ${ }^{27}$ In an in vitro transcription reaction, both the $m^{7} G\left(5^{\prime}\right) p p p\left(5^{\prime}\right) A$ and $m^{7} G\left(5^{\prime}\right) p p p\left(5^{\prime}\right) G$ cap analog can be used equally well, although the latter places an unrelated extra $G$ nucleotide upstream of the viral 5'-end, but that addition does not alter the infectivity or replication of synthetic RNA. ${ }^{27}$ Moreover, removal of the cDNA template from the RNA transcripts by DNase I digestion is not necessary for RNA infectivity tests, because the cDNA template itself is not infectious. $^{27}$

The BAC technology has now been applied to constructing infectious cDNA clones for a handful of positive-strand RNA viruses, namely, two JEVs, CNU/LP2 27 and $\mathrm{SA}_{14}-14-2^{28}$ (genome size, $\left.\sim 11 \mathrm{~kb}\right)$; two dengue viruses, $\mathrm{BR}^{24} \mathrm{O}^{26}$ and NGC ${ }^{29}(\sim 11 \mathrm{~kb})$; the bovine viral diarrhea virus, SD1 ( 12 kb); ${ }^{25}$ two classical swine fever viruses, $C$ and Paderborn $(\sim 12 \mathrm{~kb}) ;{ }^{24}$ the border disease virus, Gifhorn $(\sim 12 \mathrm{~kb}) ;{ }^{24}$ the porcine reproductive and respiratory syndrome virus, PL97-1/LP1 $(\sim 15 \mathrm{~kb}) ;{ }^{30}$ the transmissible gastroenteritis virus, PUR46-MAD ( 29 kb); ${ }^{16}$ the feline infectious peritonitis virus, DF-2 $(\sim 29 \mathrm{~kb}){ }^{32}$ the severe acute respiratory syndrome coronavirus, Urbani $\left.(\sim 30 \mathrm{~kb})\right)^{9}$ the Middle East respiratory syndrome coronavirus, EMC/2012 ( 30 kb) $;^{17}$ and the human coronavirus, OC43 ( 31 kb). ${ }^{31}$ The main advantage of using BACs for cDNA 
construction is the high genetic stability of the large, 1- or 2-copy BAC plasmids; however, the intrinsic nature of its extremely low-copy number is also a great disadvantage, because of very low yields of BAC DNA and the consequent reduction in the purity of the BAC DNA with respect to host chromosomal DNA. In the current protocol, the yield of BAC DNA is maximized by growing $E$. coli DH10B transformed with the infectious $\mathrm{BAC}$ pBAC/SA $14-14-2$ in a nutrient-rich medium, $2 \mathrm{xYT}$. Despite this effort, the average yield is only $\sim 15 \mu \mathrm{g}$ of BAC DNA from $500 \mathrm{ml}$ of $2 \mathrm{xYT}$ broth. Also, the purity of the BAC DNA is best achieved by using $\mathrm{CsCl}-\mathrm{EtBr}$ density gradient centrifugation for purification, rather than the commonly used column-based plasmid isolation. However, it is important to keep in mind that the BAC-transformed E. coli should not overgrow because it might jeopardize the genetic stability of the cloned cDNA, and higher growth does not necessarily lead to greater yields or higherpurity BAC DNA.

The protocol described here is an optimized, efficient, and streamlined method for the construction and propagation of a genetically stable fulllength infectious CDNA clone as a BAC for JEV, a procedure once thought practically impossible. This same cloning strategy may also be applied to many other positive-strand RNA viruses. In general, infectious cDNA clones enable us to introduce a variety of mutations (e.g., deletions, insertions, and point mutations) into a viral RNA genome to study their biological functions in viral replication and pathogenesis. This cDNAbased reverse genetics system makes it possible to develop and test vaccine and therapeutic candidates targeting a virulence factor(s) of a particular positive-strand RNA virus of interest. In addition, this infectious cDNA technology can also be utilized as a viral vector, capable of expressing a foreign gene(s) of interest for many applications in biomedical research.

\section{Disclosures}

The authors have declared that they have no competing financial interests.

\section{Acknowledgements}

The authors would like to acknowledge the Utah Science Technology and Research fund for support of YML and the Korea National Research Foundation grants (2009-0069679 and 2010-0010154) for support of SIY. This research was supported by the Utah Agricultural Experiment Station, Utah State University, and approved as journal paper number UAES \#8753. Also, the authors thank Dr. Deborah McClellan for editorial assistance.

\section{References}

1. Bridgen, A. Reverse genetics of RNA viruses: applications and perspectives. West Sussex, UK, Wiley-Blackwell. (2013).

2. Taniguchi, T., Palmieri, M., Weissmann, C. QB DNA-containing hybrid plasmids giving rise to QB phage formation in the bacterial host. Nature. 274 (5668), 223-228 (1978).

3. Racaniello, V.R., Baltimore, D. Cloned poliovirus complementary DNA is infectious in mammalian cells. Science. 214 (4523), 916-919 (1981).

4. Stobart, C.C., Moore, M.L. RNA virus reverse genetics and vaccine design. Viruses. 6 (7), 2531-2550 (2014).

5. Boyer, J.C., Haenni, A.L. Infectious transcripts and cDNA clones of RNA viruses. Virology. 198 (2), 415-426 (1994).

6. Ahlquist, P., French, R., Janda, M., Loesch-Fries, L.S. Multicomponent RNA plant virus infection derived from cloned viral cDNA. Proc Natl Acad Sci U S A. 81 (22), 7066-7070 (1984).

7. Ahlquist, P., Janda, M. cDNA cloning and in vitro transcription of the complete brome mosaic virus genome. Mol Cell Biol. 4 (12), 2876-2882 (1984).

8. Ruggli, N., Rice, C.M. Functional cDNA clones of the Flaviviridae: strategies and applications. Adv Virus Res. 53, 183-207 (1999).

9. Almazan, F., et al. Construction of a severe acute respiratory syndrome coronavirus infectious cDNA clone and a replicon to study coronavirus RNA synthesis. J Virol. 80 (21), 10900-10906 (2006).

10. Yount, B., Denison, M.R., Weiss, S.R., Baric, R.S. Systematic assembly of a full-length infectious cDNA of mouse hepatitis virus strain A59. J Virol. 76 (21), 11065-11078 (2002).

11. Yount, B., et al. Reverse genetics with a full-length infectious cDNA of severe acute respiratory syndrome coronavirus. Proc Natl Acad Sci $U$ $S$ A. 100 (22), 12995-13000 (2003).

12. Masters, P.S., Rottier, P.J. Coronavirus reverse genetics by targeted RNA recombination. Curr Top Microbiol Immunol. 287, 133-159 (2005).

13. Thiel, V., Siddell, S.G. Reverse genetics of coronaviruses using vaccinia virus vectors. Curr Top Microbiol Immunol. 287, 199-227 (2005).

14. Donaldson, E.F., et al. Systematic assembly of a full-length infectious clone of human coronavirus NL63. J Virol. 82 (23), 11948-11957 (2008).

15. Scobey, T., et al. Reverse genetics with a full-length infectious cDNA of the Middle East respiratory syndrome coronavirus. Proc Natl Acad Sci U S A. 110 (40), 16157-16162 (2013).

16. Almazan, F., et al. Engineering the largest RNA virus genome as an infectious bacterial artificial chromosome. Proc Natl Acad Sci U S A. 97 (10), 5516-5521 (2000).

17. Almazan, F., et al. Engineering a replication-competent, propagation-defective Middle East respiratory syndrome coronavirus as a vaccine candidate. MBio. 4 (5), e00650-00613 (2013).

18. Lai, M.M. The making of infectious viral RNA: No size limit in sight. Proc Natl Acad Sci U S A. 97 (10), 5025-5027 (2000).

19. O'Connor, M., Peifer, M., Bender, W. Construction of large DNA segments in Escherichia coli. Science. 244 (4910), 1307-1312 (1989).

20. Shizuya, $\mathrm{H}$., et al. Cloning and stable maintenance of 300-kilobase-pair fragments of human DNA in Escherichia coli using an F-factor-based vector. Proc Natl Acad Sci U S A. 89 (18), 8794-8797 (1992).

21. Stone, N.E., et al. Construction of a $750-\mathrm{kb}$ bacterial clone contig and restriction map in the region of human chromosome 21 containing the progressive myoclonus epilepsy gene. Genome Res. 6 (3), 218-225 (1996).

22. Monaco, A.P., Larin, Z. YACs, BACs, PACs and MACs: artificial chromosomes as research tools. Trends Biotechnol. 12 (7), $280-286$ (1994).

23. Preston, A. Choosing a cloning vector. Methods Mol Biol. 235, 19-26 (2003).

24. Rasmussen, T.B., et al. Generation of recombinant pestiviruses using a full-genome amplification strategy. Vet Microbiol. 142 (1-2), 13-17 (2010). 
25. Fan, Z.C., Bird, R.C. An improved reverse genetics system for generation of bovine viral diarrhea virus as a BAC cDNA. J Virol Methods. 149 (2), 309-315 (2008).

26. Suzuki, R., de Borba, L., Duarte dos Santos, C.N., Mason, P.W. Construction of an infectious cDNA clone for a Brazilian prototype strain of dengue virus type 1: characterization of a temperature-sensitive mutation in NS1. Virology. 362 (2), 374-383 (2007).

27. Yun, S.I. Kim, S.Y. Rice, C.M. Lee, Y.M. Development and application of a reverse genetics system for Japanese encephalitis virus. J Virol. 77 (11), 6450-6465 (2003).

28. Yun, S.I., et al. A molecularly cloned, live-attenuated Japanese encephalitis vaccine $\mathrm{SA}_{14}-14-2$ virus: a conserved single amino acid in the ij hairpin of the viral E glycoprotein determines neurovirulence in mice. PLoS Pathog. 10 (7), e1004290 (2014).

29. Usme-Ciro, J.A., Lopera, J.A., Enjuanes, L., Almazan, F., Gallego-Gomez, J.C. Development of a novel DNA-launched dengue virus type 2 infectious clone assembled in a bacterial artificial chromosome. Virus Res. 180, 12-22 (2014).

30. Choi, Y.J., Yun, S.I., Kang, S.Y., Lee, Y.M. Identification of 5' and 3' cis-acting elements of the porcine reproductive and respiratory syndrome virus: acquisition of novel 5' AU-rich sequences restored replication of a 5'-proximal 7-nucleotide deletion mutant. $J$ Virol. 80 (2), $723-736$ (2006).

31. St-Jean, J.R., et al. Recovery of a neurovirulent human coronavirus OC43 from an infectious cDNA clone. J Virol. 80 (7), $3670-3674$ (2006).

32. Balint, A., et al. Molecular characterization of feline infectious peritonitis virus strain DF-2 and studies of the role of ORF3abc in viral cell tropism. J Virol. 86 (11), 6258-6267 (2012).

33. Thiel, H.J., et al. Family Flaviviridae. In: Virus taxonomy: eighth report of the International Committee on Taxonomy of Viruses. Fauquet, C.M., Mayo, M.A., Maniloff, J., Desselberger, U., \& Ball, L.A., eds. San Diego, CA, Elsevier Academic Press, 981-998 (2005).

34. Yun, S.I., Lee, Y.M. Japanese encephalitis virus: molecular biology and vaccine development. In: Molecular biology of the flavivirus. Kalitzky, M., \& Borowski, P., eds. Norwich, UK, Horizon Scientific Press, 225-271 (2006).

35. Gubler, D.J., Kuno, G., Markoff, L. Flaviviruses. In: Fields virology. Knipe, D.M., et al., eds. Philadelphia, PA, Lippincott Williams \& Wilkins Publishers, 1153-1252 (2007).

36. Solomon, T. Control of Japanese encephalitis-within our grasp? N Engl J Med. 355 (9), 869-871 (2006).

37. Halstead, S.B., Jacobson, J. Japanese encephalitis. Adv Virus Res. 61, 103-138 (2003).

38. Endy, T.P., Nisalak, A. Japanese encephalitis virus: ecology and epidemiology. Curr Top Microbiol Immunol. 267, 11-48 (2002).

39. Campbell, G.L., et al. Estimated global incidence of Japanese encephalitis: a systematic review. Bull World Health Organ. 89 (10), 766-774, 774A-774E (2011)

40. Tsai, T.F. New initiatives for the control of Japanese encephalitis by vaccination: minutes of a WHO/CVI meeting, Bangkok, Thailand, 13-15 October 1998. Vaccine. 18 Suppl 2, 1-25 (2000).

41. Sumiyoshi, H., et al. Complete nucleotide sequence of the Japanese encephalitis virus genome RNA. Virology. 161 (2), $497-510$ (1987).

42. Yun, S.I., et al. Molecular characterization of the full-length genome of the Japanese encephalitis viral strain K87P39. Virus Res. 96 (1-2), 129-140 (2003).

43. Yun, S.I., Lee, Y.M. Japanese encephalitis: the virus and vaccines. Hum Vaccin Immunother. 10 (2), $263-279$ (2014).

44. Lindenbach, B.D., Thiel, H.J., Rice, C.M. Flaviviridae: the viruses and their replication. In: Fields virology., 5th edn. Knipe, D.M., et al., eds. Philadelphia, PA, Lippincott Williams \& Wilkins Publishers, 1101-1152 (2007).

45. Firth, A.E., Atkins, J.F. A conserved predicted pseudoknot in the NS2A-encoding sequence of West Nile and Japanese encephalitis flaviviruses suggests NS1' may derive from ribosomal frameshifting. Virol J. 6, 14 (2009).

46. Melian, E.B., et al. NS1' of flaviviruses in the Japanese encephalitis virus serogroup is a product of ribosomal frameshifting and plays a role in viral neuroinvasiveness. J Virol. 84 (3), 1641-1647 (2010).

47. Mukhopadhyay, S., Kim, B.S., Chipman, P.R., Rossmann, M.G., Kuhn, R.J. Structure of West Nile virus. Science. 302 (5643), 248 (2003).

48. Kuhn, R.J., et al. Structure of dengue virus: implications for flavivirus organization, maturation, and fusion. Cell. 108 (5), 717-725 (2002).

49. Gillespie, L.K., Hoenen, A., Morgan, G., Mackenzie, J.M. The endoplasmic reticulum provides the membrane platform for biogenesis of the flavivirus replication complex. J Virol. 84 (20), 10438-10447 (2010).

50. Brinton, M.A. Replication cycle and molecular biology of the West Nile virus. Viruses. 6 (1), 13-53 (2014).

51. Welsch, S., et al. Composition and three-dimensional architecture of the dengue virus replication and assembly sites. Cell Host Microbe. 5 (4), 365-375 (2009).

52. Pijlman, G.P., Kondratieva, N., Khromykh, A.A. Translation of the flavivirus Kunjin NS3 gene in cis but not its RNA sequence or secondary structure is essential for efficient RNA packaging. $J$ Virol. 80 (22), 11255-11264 (2006).

53. Kummerer, B.M., Rice, C.M. Mutations in the yellow fever virus nonstructural protein NS2A selectively block production of infectious particles. $J$ Virol. 76 (10), 4773-4784 (2002).

54. Leung, J.Y., et al. Role of nonstructural protein NS2A in flavivirus assembly. J Virol. 82 (10), 4731-4741 (2008).

55. Patkar, C.G., Kuhn, R.J. Yellow fever virus NS3 plays an essential role in virus assembly independent of its known enzymatic functions. $J$ Virol. 82 (7), 3342-3352 (2008).

56. Liu, W.J., Chen, H.B., Khromykh, A.A. Molecular and functional analyses of Kunjin virus infectious cDNA clones demonstrate the essential roles for NS2A in virus assembly and for a nonconservative residue in NS3 in RNA replication. $J$ Virol. 77 (14), 7804-7813 (2003).

57. Robertson, S.J., Mitzel, D.N., Taylor, R.T., Best, S.M., Bloom, M.E. Tick-borne flaviviruses: dissecting host immune responses and virus countermeasures. Immunol Res. 43 (1-3), 172-186 (2009).

58. Morrison, J., Aguirre, S., Fernandez-Sesma, A. Innate immunity evasion by dengue virus. Viruses. 4 (3), $397-413$ (2012).

59. Diamond, M.S. Mechanisms of evasion of the type I interferon antiviral response by flaviviruses. J Interferon Cytokine Res. 29 (9), $521-530$ (2009).

60. Gebhard, L.G., Filomatori, C.V., Gamarnik, A.V. Functional RNA elements in the dengue virus genome. Viruses. 3 (9), 1739-1756 (2011).

61. Markoff, L. 5'- and 3'-noncoding regions in flavivirus RNA. Adv Virus Res. 59, 177-228 (2003).

62. Paranjape, S.M., Harris, E. Control of dengue virus translation and replication. Curr Top Microbiol Immunol. 338, 15-34 (2010).

63. Yun, S.I., Choi, Y.J., Song, B.H., Lee, Y.M. 3' cis-acting elements that contribute to the competence and efficiency of Japanese encephalitis virus genome replication: functional importance of sequence duplications, deletions, and substitutions. J Virol. 83 (16), 7909-7930 (2009).

64. Song, B.H., et al. A complex RNA motif defined by three discontinuous 5-nucleotide-long strands is essential for Flavivirus RNA replication. RNA. 14 (9), 1791-1813 (2008).

65. Song, B.H., Yun, G.N., Kim, J.K., Yun, S.I., Lee, Y.M. Biological and genetic properties of SA $14-14-2$, a live-attenuated Japanese encephalitis vaccine that is currently available for humans. J Microbiol. 50 (4), 698-706 (2012). 
66. TRIzol LS Reagent [package insert]. Life Technologies., Carlsbad, CA, November 15, 2010. https://tools.lifetechnologies.com/content/sfs/ manuals/trizol_Is_reagent.pdf. Accessed December 01, (2014).

67. SuperScript III Reverse Transcriptase [package insert]. Invitrogen., Carlsbad, CA, December 07, 2004. https://tools.lifetechnologies.com/ content/sfs/manuals/superscriptIII_man.pdf. Accessed December 01, (2014).

68. PCR Using Q5 High-Fidelity DNA Polymerase [package insert]. New England Biolabs., Ipswich, MA, December 13, (2013).

69. Sambrook, J., Russell, D.W. Molecular cloning: a laboratory manual. 3rd edn, Cold Spring Harbor, NY, Cold Spring Harbor Laboratory Press. (2001).

70. PureLink Quick Plasmid Miniprep Kits [Quick Reference]. Life Technologies., Carlsbad, CA, April 25, 2011. https://tools.lifetechnologies.com/ content/sfs/manuals/purelink_quick_plasmid_qrc.pdf. Accessed March 10, (2015).

71. PureLink HiPure Plasmid Filter Purification Kits [User Guide]. Life Technologies., Carlsbad, CA, May 02, 2011. https:// tools.lifetechnologies.com/content/sfs/manuals/purelink_hipure_plasmid_filter_purification_man.pdf. Accessed March 10, (2015).

72. SP6 Polymerase [product information]. New England Biolabs., Ipswich, MA, January 01, (2015).

73. Kim, J.K., et al. Profiling of viral proteins expressed from the genomic RNA of Japanese encephalitis virus using a panel of 15 region-specific polyclonal rabbit antisera: implications for viral gene expression. PLoS One. 10 (4), e0124318, 10.1371/journal.pone.0124318 (2015).

74. Sumiyoshi, H., Hoke, C.H., Trent, D.W. Infectious Japanese encephalitis virus RNA can be synthesized from in vitro-ligated cDNA templates. J Virol. 66 (9), 5425-5431 (1992).

75. Mishin, V.P., Cominelli, F., Yamshchikov, V.F. A 'minimal' approach in design of flavivirus infectious DNA. Virus Res. 81 (1-2), 113-123 (2001).

76. Sumiyoshi, H., Tignor, G.H., Shope, R.E. Characterization of a highly attenuated Japanese encephalitis virus generated from molecularly cloned cDNA. J Infect Dis. 171 (5), 1144-1151 (1995).

77. Pu, S.Y., et al. Successful propagation of flavivirus infectious cDNAs by a novel method to reduce the cryptic bacterial promoter activity of virus genomes. J Virol. 85 (6), 2927-2941 (2011).

78. Yamshchikov, V., Mishin, V., Cominelli, F. A new strategy in design of +RNA virus infectious clones enabling their stable propagation in E. coli. Virology. 281 (2), 272-280 (2001).

79. Kim, J.M., et al. A single N-linked glycosylation site in the Japanese encephalitis virus prM protein is critical for cell type-specific prM protein biogenesis, virus particle release, and pathogenicity in mice. J Virol. 82 (16), 7846-7862, 10.1128/JVI.00789-08 (2008).

80. Yun, S.I., et al. Engineering the Japanese encephalitis virus RNA genome for the expression of foreign genes of various sizes: implications for packaging capacity and RNA replication efficiency. J Neurovirol. 13 (6), 522-535, 10.1080/13550280701684651 (2007).

81. Yun, S.I., et al. Japanese encephalitis virus-based replicon RNAs/particles as an expression system for HIV-1 Pr55 Gag that is capable of producing virus-like particles. Virus Res. 144 (1-2), 298-305, 10.1016/j.virusres.2009.04.014 (2009). 